\title{
Chapter 10 \\ The Importance of Reintroducing \\ Large Carnivores: The Brown Bear \\ in the Pyrenees
}

\author{
Santiago Palazón
}

\begin{abstract}
Large carnivores are keystone species in the ecosystems where they inhabit. Their loss may provoke an imbalance at several levels of the ecosystem. Conservation strategies for existing populations of large carnivores and restoration programmes of disappeared populations can help at maintaining the ecosystem balance and foster the perception links of humans with nature. The case of the restoration of the brown bear population in the Pyrenees during the last 20 years is a successful example of conservation measures carried out to assure the coexistence between this species and the local society, which economy is based on extensive livestock, beekeeping and tourism. In this chapter, I describe the role of large carnivores in mountain ecosystems and the context and development of the of the brown bear in the Catalan Pyrenees as an example of the challenges of large carnivore conservation in a rural context but a high influence from nearby urban areas.
\end{abstract}

Keywords Large Carnivores - Bear - Wolf • Population restauration · Mountains

\subsection{Introduction}

Large carnivores are characterised by their large size and for being apex predators, i.e. predators at the top of the food web (Edwards 2014). Populations of large carnivores are typically at low densities and with low reproductive potential partly because of their large spatial requirements and their vulnerability to habitat destruction (Rosenblatt et al. 2013; Noss et al. 1996). This feature makes populations of large carnivores especially vulnerable to catastrophic events or continued declines, from which they recover slowly (Edwards 2014). Doing research on large carnivores is also difficult because of the time scale, geographical scope and high costs involved (Estes 1996). Historically in Europe, they have competed for food

\footnotetext{
S. Palazón $(\bowtie)$

Fauna and Flora Service, Ministry of Territory and Sustainability, Government of Catalonia, Dr. Roux, 80, 08017 Barcelona, Spain e-mail: santiago.palazon@gencat.cat
} 
resources and space with humans and continue to do so. Some can be dangerous to humans and are considered fearsome. Human attitudes are an important component of large carnivore management and conservation (Piédallu et al. 2016). Attitudes towards large carnivores of humans co-inhabiting places with them are not always of acceptance.

There are five large carnivores in Europe: the brown bear (Fig. 10.1), the wolf, the European lynx, the Iberian lynx and the wolverine. The first three are distributed in different locations throughout Europe, whereas the last two live at the furthest distance from each other but still within the geographical limits of Europe: the Iberian lynx in the Southern Iberian Peninsula and the wolverine in Northern Scandinavia and Russia.

The conservation of these five large European carnivores is a priority for the European Union and Nature2000. In the words of the Large Carnivore Initiative for Europe's (LCIE; www.lcie.org) member John Linnell, "People familiar with the presence of large carnivores know how to adapt to them, but because these large carnivores were gone for so long, we have forgotten how to share our living space with large, hairy and potentially dangerous animals. When large carnivores reappear, we have to adapt our way of taking care of livestock again". Therefore, with the slogan "Working together across the European Union to conserve and manage large carnivores", LCIE works to conserve Europe's large carnivores through the protection afforded by the Habitat Directive, based on the premises of human safety, the protection of livestock with means and measures, and awareness campaigns for local human populations.

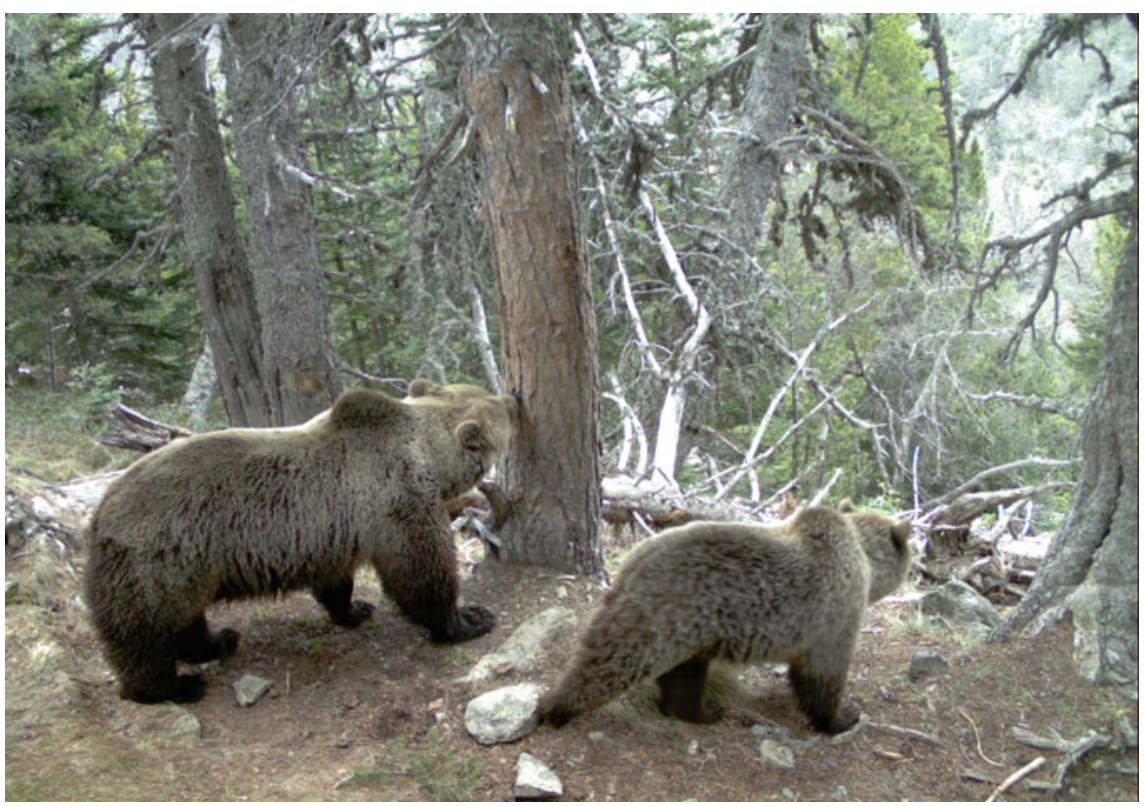

Fig. 10.1 Male and female brown bears together in May 2016, Pyrenees 
Human populations have for long displaced large carnivores populations thought, e.g. hunting, urban development and habitat loss, being displaced to unmanaged and protected natural environments. However, the opposite is now happening in Europe: populations of large carnivores are increasing the occupied territory, including places with human populations are dense with almost 100 people per square kilometre (Chapron et al. 2014; Boitani et al. 2015). Except for the Iberian lynx, large European carnivores are making a comeback in Europe. One-third of the European territory is now home to at least one large carnivore. Compared to figures from the mid-twentieth century, current populations remain stable or are on the rise. For example, Europe now boasts a population of 18,000 bears and 12,000 wolves (Naves et al. 2015; Chapron et al. 2014). The recovery of these populations of large carnivores is partly due to the change in the social to more positive perceptions and attitudes towards large carnivores.

The processes regulating the population and community dynamics of the large carnivores include bottom-up forces such as primary production (soil, $\mathrm{CO}_{2}$ and $\mathrm{H}_{2} \mathrm{O}$ ), nutrient dynamics (nitrogen, phosphorus, potassium and others) and energy cycles; top-down forces such as predation, risk effects and trophic cascades; non-predatory interactions, including facilitation and inter- and intra-specific competition for resources; and pulse and press disturbance and perturbation events such as fires, storms, wave action, floods and drought (Rosenblatt et al. 2013; Estes et al. 2001). Alternative stable states occur when perturbations of sufficient magnitude and direction push ecosystems from one basin of attraction to another (Estes et al. 2011). Trophic cascades are defined by Estes et al. (2011) and Paine (1980) as "the propagation of impacts by consumers on their prey downward through food webs" and by Edwards (2014) as "a series of interactions at more than one trophic level where apex predators suppress mesopredators or prey, leading to an increase in number and/or diversity of primary producers".

Large predators are keystone species for the ecosystems, i.e. they are at relatively low abundance and biomass, but have a large ecological effect on its community or the ecosystem (Power et al. 1996; Miller et al. 2001). The disappearance or reduction of these keystone species may lead to increases in the (now uncontrolled by top predation) mesopredators and preys and therefore a reduction of primary resources.

\subsection{The Benefits of Large Predators}

What role do large carnivores play in an ecosystem? This is not an easy question to answer. Apex predators ensure biodiversity. They are the engineers of the ecosystem because they can change its dynamics and increase habitat heterogeneity and biodiversity (Ritchie et al. 2012). They prevent the spread of diseases and invasive species. They also maintain the physical and chemical conditions of the soil and water (Estes et al. 2011). They can connect different, often distant, habitats and their behaviour affects biogeochemical and nutrient dynamics. How do large carnivores affect ecosystems? Mainly in two ways: through prey control and 
mesopredator control. Because of the effects apex predators have on an ecosystem, their presence benefits the ecosystem as a whole. To revisit the previous example, when populations of sea otters began to increase in the Aleutian archipelago, sea urchin numbers dropped, the kelp forest grew and the number of fish increased.

\subsection{Impacts on Preys}

Large carnivores control prey populations by direct and indirect means. Carnivores directly reduce the number of preys through predation (Terborgh 1988; Terborgh et al. 1997; Estes et al. 1998; Miller et al. 2001). Their impact on populations of prey species is a form of biological control. Apex predators limit the number of herbivores and reduce pressure on plants (first and third trophic levels). For example, the wolf (Canis lupus) and the lynx (Lynx sp.) prey on ungulate populations (Jedrzejewski et al. 1993; Okarma 1995; Valdmann et al. 2005). The brown bear preys on ungulates to a lesser degree (Vulla et al. 2009), but in Northern Europe, it preys heavily on the calves of reindeer (Rangifer tarandus) and moose (Alces alces) (Swenson et al. 2007) and in North America, the brown bear and black bear are major predators of neonatal ungulates (Zager and Beecham 2006). In Bialowieza, Poland, the wolf and lynx prey significantly on small ungulates, but less on wild boar (Sus scrofa), moose and bison (Bison bison) since their numbers are limited by food availability and weather conditions such as snow (Jedrzejewska and Jedrzejewski 2005). In Norwegian forests, roe deer (Capreolus capreolus) density declined predators were present in the habitat (Melis et al. 2009). The population went from 1485 roe deer individuals per $100 \mathrm{~km}^{2}$ when there were no predators to 605 with one predator (European lynx or wolf) and 167 with both predators.

Carnivores' indirect control has effects on resources, preys behaviour and diseases. It causes prey species to alter their behaviour to reduce their vulnerability (McLaren and Peterson 1994; Fitzgibbon and Lazarus 1995; Schmitz 1998; Brown 1999; Miller et al. 2001). The prey chooses different habitats, food sources, group sizes and activity times, and reduces the amount of time used for feeding (Miller et al. 2001). If a predator selects from a wide range of prey species, the predator's presence may cause all prey species to reduce their respective niches, thus reducing competition among these species. Prey species compete for limited resources and decrease the diversity through competitive exclusion (Paine 1966; Terborgh et al. 1997). The control on preys also becomes a sanitary control because it prevents the proliferation of infectious diseases among prey populations (Miller et al. 2001). Predation risk by wolves affects the number and behaviour of moose on Isle Royale (McLaren and Peterson 1994), as well as elk (Cervus elaphus) behaviour in Yellowstone National Park (Ripple and Beschta 2006). This herbivore control, in turn, mainly affects the balsam fir forest by regulating seedling establishment, sapling recruitment, sapling growth rates, litter production in the forest and soil nutrient dynamics (Pastor et al. 1988; Post et al. 1999, 2000; Miller et al. 2001). In Shark Bay, Australia, a prey species of the tiger shark (Galeocerdo cuvier) altered 
its behaviour and habitat use in the presence of the shark to balance the risk of predation and its foraging (Heithaus et al. 2012). These behavioural changes cascade to the seagrass community by altering its biomass, structure, composition and nutrient dynamics (Burkholder et al. 2013).

\subsection{Impact on Mesopredators}

Besides impacting on preys, large predators also have a bearing on mesopredators (i.e., medium-sized predators) by decreasing their densities and reducing competition among both (Palomares and Caro 1999). In Norway, the European lynx preys on red foxes (Sunde et al. 1999), whereas in Australia the dingo (Canis dingo) preys on introduced red foxes and feral domestic cats (an invasive species in Australia), and has positive effects on native medium-sized marsupials (Letnic et al. 2012). Therefore, in Australia, introducing the dingo to reduce invasive mesopredators is better than using lethal control with poison (Letnic et al. 2012). Large predators also have an indirect impact by modifying the behaviour of other predators through the creation of "fear landscapes", i.e. areas of the territory that are avoided by mesopredators due to the presence of large predators (Sergio et al. 2008), as the use of trails and paths (Hayward and Marlow 2014).

However, large predators can also produce the opposite effect on mesopredators, by having a positive effect on them. Eagles, vultures, nocturnal raptors, foxes, martens, wild boars, raccoons, dogs and other small predators and omnivores take advantage of the increase in food left by large predators in the form of carrion (especially during heavy winters) (Fig. 10.2).

\subsection{Others Impacts on Ecosystems}

Individual specialisation of large top predator behaviours also affects ecosystems (Rosenblatt et al. 2013). Direct impact includes transporting nutrients between habitats (Holtgrieve and Schindler 2011). Predators can also act as vectors between different habitats, potentially affecting nutrient and biogeochemical dynamics through localised behaviours (Rosenblatt et al. 2013). Predators have an indirect impact by affecting nutrient transport between ecosystems by acting on prey species that transport nutrients (Croll et al. 2005; Maron et al. 2006; Rosenblatt et al. 2013). Large predators may contribute to the creation of heterogeneous nutrient patterns in ecosystems through their own nutrient recycling (nitrogen and phosphorus), thus inducing behavioural modifications in prey species that affect the distribution of nutrients (Schmitz et al. 2000). This interaction may enable large top predators to strongly influence the structure, composition and spatial patterns of local areas through their participation in bottom-up processes (Rosenblatt et al. 2013). This behaviour could create hotspots of foraging and nutrient recycling. 


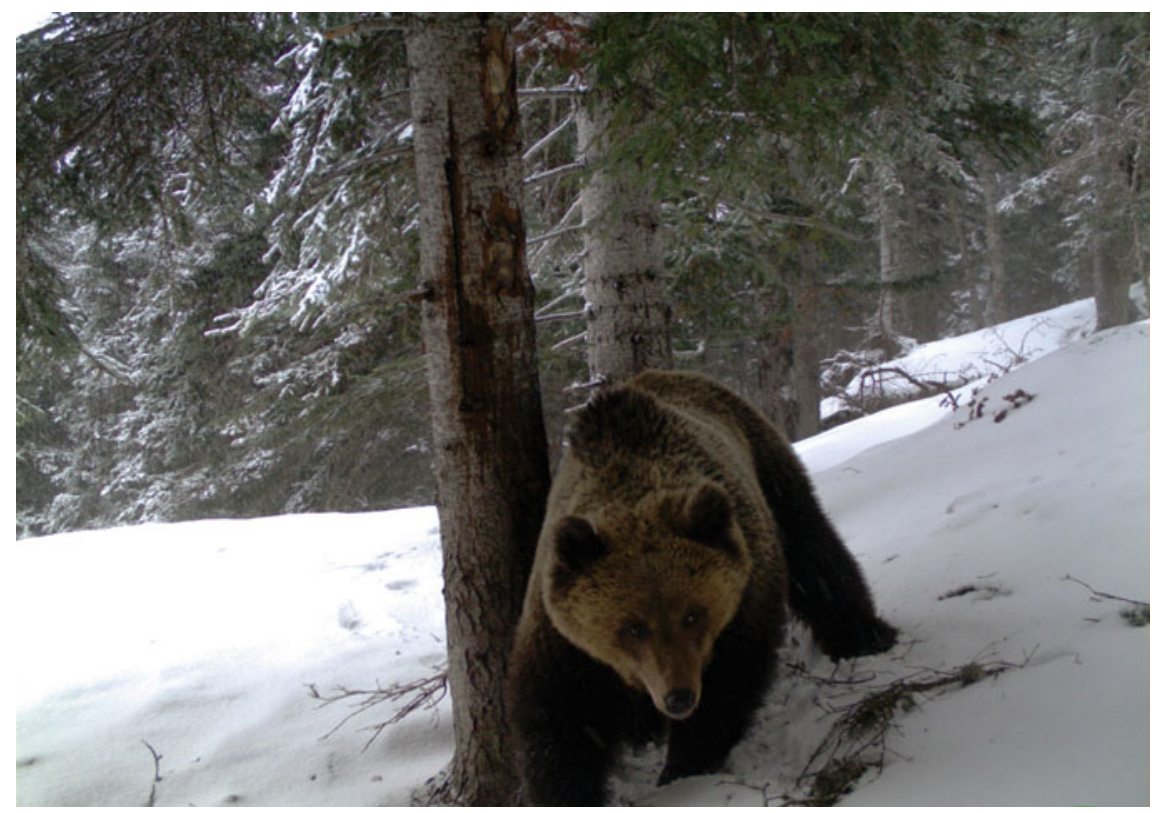

Fig. 10.2 Male brown bear born in the Pyrenees (March 2004)

Some examples of this can be found in terrestrial and marine ecosystems. By relocating salmon carcases from streams to riparian areas and through the consumption and excretion of salmon-derived nutrients, the Alaskan brown bear is responsible for up to $24 \%$ of riparian nitrogen budgets (Helfield and Naiman 2006). Arctic foxes in the Aleutian archipelago can reduce seabird-mediated nutrient inputs from the ocean to terrestrial areas, thus cause grassland habitats to shift to dwarf shrub/forb-dominated ecosystems (Croll et al. 2005; Maron et al. 2006). Bull sharks (Carcharinus leucas) move between the different habitats of the Shark River Estuary in Florida and link these habitats through trophic interactions (Matich et al. 2011). Such behaviours by these large mobile consumers may lead to transport of limiting nutrients from relatively nutrient-rich marine habitats to oligotrophic freshwater/estuarine habitats, which could affect community composition of primary producers (Rosenblatt et al. 2013). The reintroduction of wolves in Yellowstone Park has reduced the positive indirect effects of ungulates on soil nitrogen mineralisation and potentially the nitrogen supply for plant growth (Frank 2008). The introduction of rats and arctic foxes has reduced soil fertility and plant nutrition on high-latitude islands by disrupting seabirds and their sea-to-land nutrient subsidies, and this has had striking effects on plant community composition (Wardle et al. 2007). A linked process of consumption and excretion can recycle nutrients such as nitrogen and phosphorus to similar ratios of other sources of nutrients and contribute to heterogeneity in nutrient dynamics, thus increasing process diversity. 


\subsection{What Happens When Large Predators Disappear?}

Since the Late Pleistocene, over-exploitation, hunting, agriculture, livestock, habitat loss and destruction have had a major impact on the populations of large carnivores living in terrestrial and marine habitats. As human civilisation has progressed, human density has massively increased, and the populations of large carnivores have decreased or been eliminated. As a result, large predators have been entirely removed from the system in many areas, or their numbers have been severely reduced (Weber and Rabinowitz 1996; Terborgh et al. 1999; Woodroffe 2000; Miller et al. 2001).

The loss of large carnivores has long-term effects on ecosystem stability (Miller et al. 2001). Because they have disappeared from large territories where they once lived, top-down processes previously regulated by them have been considerably altered (Rosenblatt et al. 2013). Trophic chains and cascades shorten, and animal and plant populations suffer alterations in their numbers and dynamics. Without top predators, populations of prey species increase; the increase of herbivores leads to greater pressure on plants, reducing vegetation cover and increasing the prevalence of diseases. Changes in animal and plant populations, also alter nutrient and biogeochemical cycles (soil and water) (Estes et al. 2011, Ritchie and Johnson 2009). In the absence of top predators, mesopredator populations increase, thus leading to so-called "mesopredator release" (Soulé et al. 1988) and a decline in populations of smaller prey species. Summarising, the loss of predators limits the ecosystem's ability to restore the process of top-down control.

Apex predators have disappeared from different ecosystems. The extirpation of large top predators in Northern Arizona in the early twentieth century led to the irruption (sudden and rapid increase) of the mule deer (Odocoileus hemionus) population, which caused over-browsing, a reduction in woody browse cover and eventually famine among the deer (Rosenblatt et al. 2013; Binkley et al. 2006). In Yellowstone National Park, the extirpation of wolves in the early twentieth century led to an increase in the elk (Cervus elaphus) population, a concomitant decrease in the recruitment of deciduous tree species and related effects on ecosystem structure and function (Ripple and Beschta 2012; Rosenblatt et al. 2013). In the Aleutian archipelago, the arctic fox (Alopex sp.) limits the number of sea birds, thus decreasing the amount of nutrients transported from sea to land and maintaining the herbaceous structure of the tundra (Croll et al. 2005). When sea otters (Enhydra lutris) were overexploited by the fur trade in the North Pacific, marine invertebrate herbivores increased in number, especially sea urchins (Strongylocentrotus spp.) and devastated kelp forests. This fact produced a cascade of indirect effects that reduced diversity in fish, shorebirds, invertebrates and raptors (Estes 1996; Estes and Duggins 1995; Miller et al. 2001; Estes et al. 2003). After 7 years of isolation in the recently formed Lago Guri reservoir in Venezuela, nearly $75 \%$ of the vertebrate species have disappeared from the scattered islands that are too small to hold the jaguar (Panthera onca) or the puma (Puma concolor). The few species that remain are hyper-abundant and have gross effects on the plant community. There is also little regeneration of the canopy trees (Terborgh et al. 1997). 


\subsection{The Situation of the Brown Bear, Wolf and European Lynx in the Pyrenees}

The native brown bear population in the Pyrenees disappeared during the last 10 years, although the population located in the Central Pyrenees was wiped out earlier in the 1990s (Camarra and Parde 1990; Parellada et al. 1995; Alonso et al. 1993; Casanova 2005). The last female bear died in 2004, along with the oldest male, and the last male died in 2010 (DARP 2015). Currently, there is only one male born from a released Slovenian male and the last Pyrenees female. The current bear population (Table 10.1) was reintroduced from a set of individuals captured in the Balkans (Slovenia) and released in the Pyrenees in 1996-1997 (two females and one male) in 2006 (four females and one male) (Quenette et al. 2000) and 2016 (one male). In 2016, the bear population was divided into two areas: the Central Pyrenees subpopulation, with more than 35 bears identified, and the Atlantic Pyrenees subpopulation, with only two males identified.

The wolf was once distributed throughout Catalonia (NE Spain) from the Mediterranean coast to the Pyrenees. At the end of the eighteenth century, 200-250 wolves were being hunted per year $\left(0.8\right.$ wolves per $\left.100 \mathrm{~km}^{2}\right)$, but by the beginning of nineteenth century, only 10-50 wolves per year were killed $(0.02$ wolves per $100 \mathrm{~km}^{2}$ ) (Ruiz-Olmo 1995). These data indicate the decline in the wolf population in Catalonia and the Pyrenees. Population declines and extinctions spread progressively from east to west and north to south (Ruiz-Olmo 1995). Two animals killed in 1924 and one in 1935 in the Tortosa Mountains (Southwest Catalonia) were the last wolves hunted in Catalonia (Ruiz-Olmo 1995; Aguilar-Amat 1924). The wolf had therefore disappeared from the Pyrenees by the beginning of twentieth century. However, thanks to the natural dispersal of individuals from two European populations (Italian and Cantabrian) the wolf has been living in the Pyrenees for the last 20 years. Individuals from remaining populations of wolves in northern Spain have sporadically dispersed into the western Pyrenees, but most individuals are immediately eliminated. Italian wolves can also sporadically cross the south-east France and reach the Eastern Pyrenees (France and Catalonia). France and Catalonia are now protecting this population (Table 10.2), though it is currently considered a group of lone individuals rather than a proper population.

Table 10.1 How many bears inhabit the Pyrenees Mountains?

\begin{tabular}{l|l|l}
\hline Year & Minimum determinate number & Minimum revised number $^{\mathrm{a}}$ \\
\hline 2010 & 19 & 20 \\
\hline 2011 & 22 & 23 \\
\hline 2012 & 22 & 24 \\
\hline 2013 & 25 & 28 \\
\hline 2014 & 31 & 31 \\
\hline 2015 & 29 & 32 \\
\hline 2016 & 39 & - \\
\hline
\end{tabular}

${ }^{\mathrm{a}}$ The revision of last year can change the bear number of former years 
Table 10.2 How many wolves inhabit the Pyrenees Mountains?

\begin{tabular}{l|l|l|l}
\hline Year & France & Catalonia & Eastern Pyrenees \\
\hline 2010 & 2 & 2 & 3 \\
\hline 2011 & 2 & 0 & 2 \\
\hline 2012 & 2 & 1 & 3 \\
\hline 2013 & 2 & 1 & 2 \\
\hline 2014 & $2-3 ?$ & 1 & $2-3 ?$ \\
\hline 2015 & $2-3 ?$ & 1 & $2-3 ?$ \\
\hline
\end{tabular}

The European lynx once lived in the Pyrenees (Beaufort 1965; Arribas 2004; Rodríguez-Varela et al. 2015), but probably disappeared in the second half of twentieth century (Ruiz-Olmo 2001). Today, there is no lynx in the Pyrenees, but a European lynx release pilot project is planned in Catalonian in coming years (Ruiz-Olmo et al. 2006; Magrama 2015a).

\subsection{Problems Generated by the Presence of the Brown Bear and Wolf in Catalonia and the Pyrenees}

The brown bear and wolf created problems in the Pyrenees through their attacks on livestock (sheep and goats) and beehives such as social and political conflict, fear among the locals and tourists, and their competition with hunters. The objectives of the Catalan government is: (1) to preserve large carnivore populations; (2) to conserve mountain livestock (sheep, goats, cows and horses) since the maintenance of the mosaic landscape (pastures and forests) has an important input in the economy of the mountain communities and (3) to protect mountain beekeeping activities (apiculture) because it is important for the economy of Catalan agricultural activity and because cross-pollination of mountain flora is essential for the ecosystem.

\subsection{Damage to Livestock and Beehives}

Brown bears prey on beehives and livestock (sheep and goats). They can sometimes chase away horses and cows and even wound them. Wolves prey on livestock (sheep, cows and calves, foals and shepherd dogs) and lynx also prey on livestock, mainly sheep. Between 1996 and 2015, 320 bear attacks in Catalonia caused 629 victims (369 dead sheep and goats and 249 damaged beehives) (Fig. 10.3). The annual average was 16 attacks $(\mathrm{SD}=6.44)$ and 31.45 victims $(\mathrm{SD}=18.57)$. The Catalonian government and other public administrations paid an annual average of $€ 5990$ ( $\mathrm{SD}=3045.04$ ) in compensation. This figure only includes compensation for certified bear attacks, but not compensation for political or social reasons. 
Fig. 10.3 Evolution by year of brown bear attacks (number of attacks and victims) in Catalonia: 1996-2015
Fig. 10.4 Evolution of attacks (number of victims) on domestic livestock and beehives by one brown bear in Catalonia by year: 1996-2015
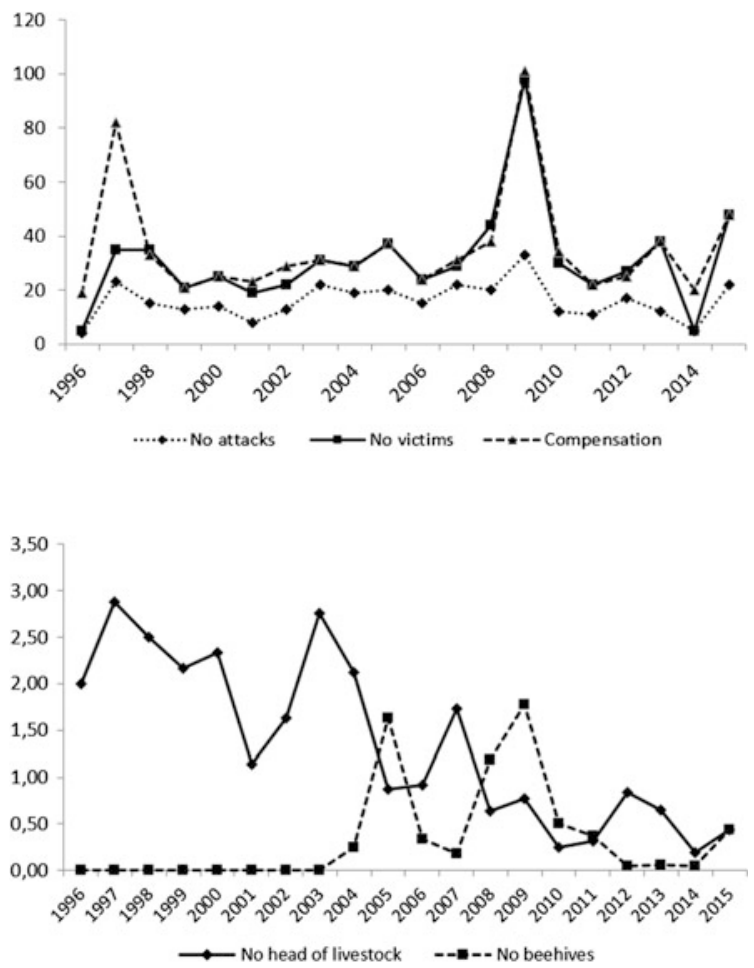

Over the years, the bear population has increased while damage has decreased or remained at similar levels. The damage caused by each bear has therefore decreased significantly (Fig. 10.4). In France, the number of attacks, victims and the cost is higher than in Catalonia (Bautista et al. 2016).

\subsection{Protective Measures Implemented in Catalonia}

The goal of the Catalan government is to reduce the damage caused by these animals effectively. Small flocks were first grouped into big ones ( $>1000$ head), and shepherds and assistants were hired to manage them. Flocks and beehives were enclosed in electrified enclosures. Protection dogs were donated to livestock owners and shepherds. The living conditions of shepherds in the mountains were improved through the construction and remodelling of cabins and shelters. The Bear Support and Conservation Teams carry out monitoring of the brown bear population. They also help in managing livestock and apiculture and provide information to stockbreeders, shepherds, hunters, tourists and town councils. All these actions entailed considerable expenditure, as well as a great deal of time and human and material resources. 


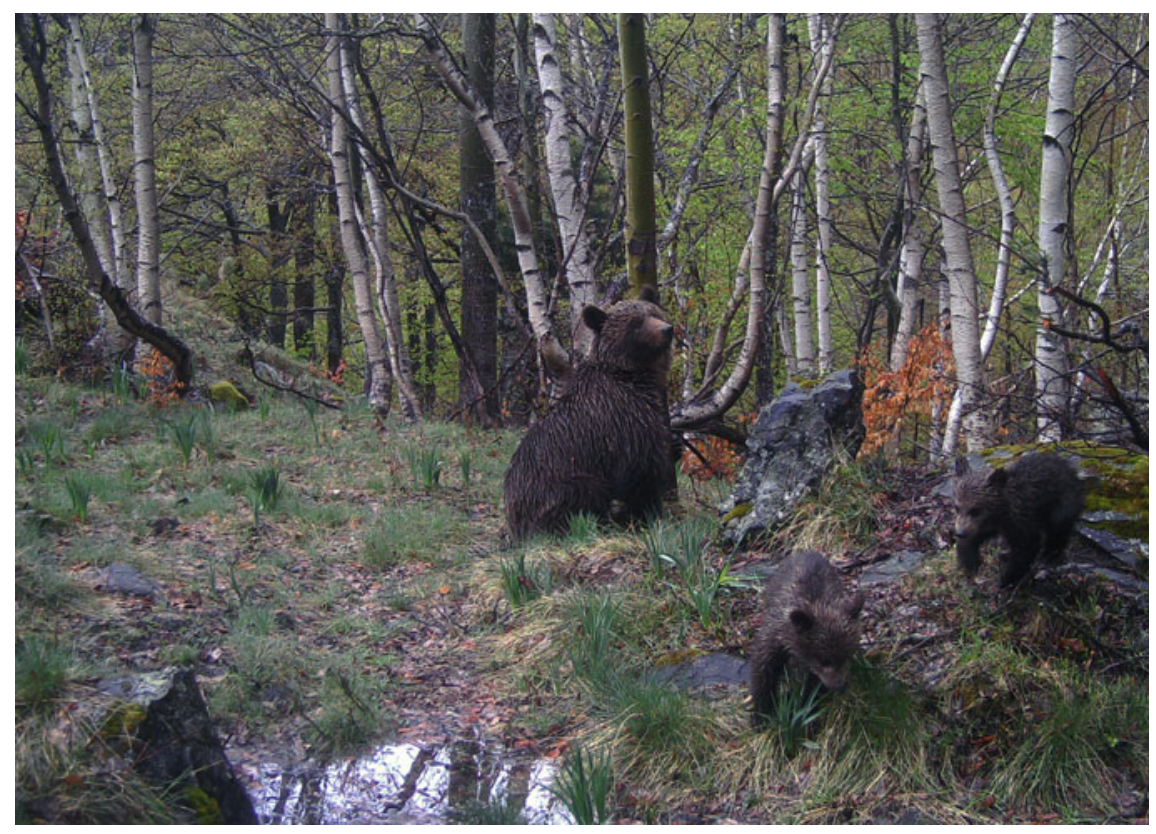

Fig. 10.5 A female bear with two cubs of the year in the Pyrenees of Catalonia (September 2016)

Although prevention is more expensive than paying compensation, it is better than paying for the damage caused by bears because it prevents social conflict. Keeping attacks and damage to a minimum is required to avoid social conflicts in regards to the presence of brown bears. Moreover, the measures applied for protection against the brown bear also set a positive precedent for the current reintroduction of the wolf and the possible future reintroduction of the lynx. The flock protection measures applied can be useful for brown bears, wolves, lynx and even feral dogs. In Catalonia, the Decree 176 of 31 July 2007 and Order AAM/147 of 8 May 2014 provide legislation on the payment of compensation for damage caused by protected species: the brown bear, wolf and vulture. The aim is to increase the density of brown bears (i.e. the number of animals in the geographic area occupied) and the area of distribution (Fig. 10.5); consequently, the number of attacks will be likely to increase. Therefore, protection measures must be implemented after the first attack to avoid more damages.

\subsection{Encounters Between Humans and Large Carnivores}

Another associated problem is the encounters between humans and large carnivores, most of them occurring with the brown bear. Due to the bear's size and power, attacks can occasionally cause severe injuries to people or even death. 
However, in Europe, attacks are scarce (Naves et al. 2015): one hunter was killed in Sweden in 2004, one person in Finland in 2006 (Ordiz 2014) and three attacks with three injured people have occurred in the Cantabrian Mountains (N Spain) during the last 25 years. There are extreme cases of wolf attacks in Russia. In close encounters with bears, people were perceived as a danger by the bear. People have to avoid dangerous situations by applying simple measures when walk or work in a forest with bears. In the Pyrenees, several encounters have occurred in last 20 years between humans and bears. In most of them, the bear slowly ran away to get away from people after it was warned of their presence. These encounters have mainly happened with bear teams and photographers. In 1997, the female Melba encountered a French hunter to defend her 3-year-old cubs. She was shot to death. In 2004, the female Cannelle faced a French hunter to protect her 1-year-old cub (Cannellito) from hunting dogs. She was also shot to death. In 2004, when the male Papillon was found dead (due to natural causes), the subsequent autopsy revealed the presence of 50 pellets inside his body. Hunters have also shot the male bears Boutxy and Kouki in France several times. In 2007, the female Francka was hit and killed by a military van on a French highway. In 2008, the female Hvala attacked a hunter when she was running away from a wild boar being hunted with dogs; she was pregnant. One hunter, who was over age 70, suffered superficial wounds in his arm, a small bite in his boot and fell and broke his leg. The government paid a compensation after the trial.

\subsection{Potential Economic Benefits Generated by the Presence of Large Carnivores}

One of the benefits that could be produced by large carnivores in the Pyrenees is tourism. There are two forms of potential tourism involving large carnivores: hunting tourism and nature tourism or ecotourism. Hunting is only possible when the species boasts a large, self-sustainable population and when studies indicate that an annual culling will not affect long-term species population. Ecotourism can be implemented fully, but clear roles must be defined to ensure the bear population is affected as little as possible.

\subsubsection{Hunting Tourism}

According to Annex II of the Directive Habitats (EU), the brown bear is a protected species. According to Annexes IV and V, the wolf and the European lynx can be hunted in accordance with the laws of each European country. In Spain, wolf hunting is permitted only under certain circumstances. However, there is currently considerable controversy among hunters, stockbreeders, the public administration 
and ecologists about the number of wolves that can be hunted and the methods that can be used. When large predators prey on ungulates, the ungulate population density drops, fewer damages are caused to agriculture and conflicts between farmers and hunters are avoided. Moreover, ungulate populations are healthier, so the spread of diseases reduces. Finally, hunting trophies are larger and more attractive to hunters.

\subsubsection{Nature Tourism}

Nature tourism mainly consists of hiking, mountaineering and animal watching. These activities have increased in recent years in several European countries and are expected to offer many opportunities in the future through the creation of services, businesses and jobs. However, it is first necessary to change the local mindset. People need to take a positive approach to the presence of large carnivores and see them as an opportunity. It will be necessary to take advantage of the positive aspects and reduce the negative effects. In the United States, this mindset shift took place 20 years ago (Mech 1996). Nature tourism is also an opportunity for environmental education. In the Pyrenees, wildlife tourism started with the brown bear in France and now in Catalonia, and can be expanded to include the wolf and the lynx. There are already a few bear observation spots in the Pyrenees, but observers must stay away from the bears to avoid interferences with their behaviour. In the future, feeding spots can be built with supplementary food, as well as observation hides for watching, photo and filming. Nature business has already taken off in the Pyrenees and tourists can now visit the areas inhabited by bears. This activity makes necessary to draft regulations to protect the animals and the habitat. It is crucial to strike a balance between conservation and business. In nature tourism, excessive disturbance of the habitat should be avoided; predators must learn to adapt to additional food and the presence of humans (family bears can be dangerous, and the final solution may be to kill these bears). Also relevant, among other factors, is the alteration of wolf behaviour and interference from young wolves (howling imitations) (Magrama 2015b). Nature tourism has an impact on brown bear behaviour (Nevin et al. 2005), and contact with humans increases the risk of death of these large carnivores (Ordiz 2014).

Nature tourism is an alternative to hunting and hunters. Unlike hunting, where an animal can only be "sold" once, nature tourism enables an animal to be "sold" several times. Associated products can also be sold. Other locations on the Iberian Peninsula have an advantage over the Pyrenees. In the Culebra Mountains, nature tourism focuses on wolf watching because it is relatively easy to watch these animals. Nature tourism in the area has generated ten times more income than hunting tourism; thus, society will have to decide if both kinds of tourism are compatible. The Cantabrian and Pyrenees Mountains are comparable in many ways, and I believe that a modified Cantabrian model could be transferred to the Pyrenees. 


\subsection{Do the Pyrenees Have Enough Room and the Right Habitats for Large Predators?}

Sainz de la Maza and Nunes (2001) studied the habitat preferences of the brown bear in Catalonia using a Geographic Information System (GIS) based on radio tracking data. The results show that the bear selected an altitude between 800 and $1800 \mathrm{~m}$ a.s.l., a north to north-east orientation, a slope of $30^{\circ}-60^{\circ}$, beech and fir and humid oak forests, a distance from villages between 1 and $2.5 \mathrm{~km}$, a distance from roads between $0.5 \mathrm{~m}$ and $2 \mathrm{~km}$, and a distance from forest trails of between 0.1 and $1 \mathrm{~km}$. The results showed that trophic and refuge interest areas accounted for 60 $70 \%$ of the territory. Martin et al. (2012) compared habitat suitability between the Cantabrian and Pyrenees Mountains and found good transposition of the Cantabrian model to the Pyrenees. However, there was a lack of balance between food resources for bears (scarce at high altitudes) and human presence (higher at low altitudes) when comparing both areas. Ruiz-Olmo et al. (in press) compared habitat selection between native bears (disappeared) and the reintroduced bears and made a model of distribution and habitat quality. The brown bear population has increased by between 9 and $15 \%$ in recent years, which means that bears have adapted to a new habitat, with high quality. The fragmented habitat has large non-available areas. The reintroduced bear population uses the same habitat as the extinct native bears. The current situation is that the number of bears is low and the maximum capacity of the environment in regard to holding brown bears has not been reached.

\subsection{Conclusion}

Large carnivores play a significant role in the ecosystem. However, to defend the presence of large carnivores, coexistence between nature and society must be achieved by providing information, raising awareness and implementing effective measures. We must understand that the first response of stockbreeders, livestock owners and shepherds might be "no bears", but it is important to keep the conversation open.

Stockbreeders have to change their mindset and the way they work. They must become true stockbreeders. Coexistence will only be possible if preventive measures are in place and attacks and damages are very scarce. These measures will avoid social unrest and keep the calm. We must apply common sense and go back to traditional methods (for instance, sheep keepers and protection dogs) focusing on today's technology. As a result of many years of livestock breeding without predators, the habit of not protecting herds has become a common practice.

The last question is why should the brown bear, wolf and lynx be reintroduced into the Pyrenees? The answer has many different components. Axe predators are endangered and protected species in Catalonia, Spain and the European Union (legal component). They are evolutionary responses to adaptation to different 
environments (scientific component). They perform a crucial ecological function and are keystone species in the ecosystem (ecological component). They are umbrella species in the sense that the results of protecting the brown bear and wolf include habitat protection and conservation of smaller species and invertebrates (conservation component). They are unrepeatable emblematic species of the Pyrenees (aesthetic component). They can revitalise the Pyrenees economy enhancing the nature tourism (economic component). These species also have the right to live in the ecosystems where they have always lived. Their disappearance was caused by human pressure from hunting, poaching and poison, and we are collectively responsible for that (ethical component).

The current situation in the Pyrenees is very different than it was 50-100 years ago. The damage caused by large carnivores does not represent an economic disaster, and compensation has been paid to cover all actual, proven cases of damage. The presence of the brown bear and wolf has not limited traditional activities in the Pyrenees and is not expected to do so in the future. There is enough room in the Pyrenees for the local human population and self-sufficient large predator populations to live together. These answers confirm that conserving, protecting and promoting large carnivore populations are positive for ecosystems and society.

Bears are similar to humans. They are generalist omnivores, intelligent and boast binocular sight (Rockwell 1991). They are similar in height when they stand up. Wolves have many of the features of human hunter-harvesters. They are members of a pack, hunt cooperatively and defend their territory (López 1978). The intrinsic recognition of the value of wildlife is on the rise, included the importance of large predators.

Acknowledgements I would like to express my thanks to the institutions and public administrations in France, Andorra, Navarra, Aragon and Catalonia on the reintroduction of the brown bear in the Pyrenees. I have worked with them since 1996. I would also like to thank the institutions and public administrations on wolf monitoring in France and Catalonia, with which I have worked since 2000 .

\section{References}

Aguilar-Amat JB (1924) Dades per un catàleg de mamífers de Catalunya. Trab Mus Cienc Nat Barcelona 7(4):3-51

Alonso M, Pando A, Toldrà L (1993) El oso pardo en Cataluña. In: Naves J, Palomero G (eds) El oso pardo en España. Colección Técnica, Icona. Madrid

Arribas O (2004) Fauna y paisaje de los Pirineos en la era glaciar. Lynx Edicions

Bautista C, Naves J, Revilla E, Fernández N, Albrecht J, Schart AK, Rigg R, Karamanlidis AA, Jerina K, Huber D, Palazón S, Kont R, Ciucci P, Groff C, Dutsov A, Seijas J, Quenette PY, Olszanska A, Shkvyria M, Adamec M, Ozolins J, Jonozovic M, Selva N (2016) Patterns and correlates of claims for brown bear damages on a continental scale. J Appl Ecology. doi:10. $1111 / 1365-2664.12708$

Beaufort F (1965) Lynx des Pyrénées, Felis. L. Lynx lynx. Mammalia 29:589-601

Binkley D, Moore MM, Romme WH, Brown PM (2006) Was Aldo Leopold right about the Kaibab deer herd? Ecosystems 9:227-241. doi:10.1007/s10021-005-0100-z 
Boitani L, Alvarez F, Anders O, Andren H, Avanzinelli E, BalysV, Blanco JC, Breitenmoser U, Chapron G, Ciucci P, Dutsov A, Groff C, Huber D, Ionescu O, Knauer F, KojolaI, Kubala J, Kutal M, Linnell J, Majic A, MannilP, Manz R, Marucco F, Melovski D, Molinari A, Norberg H, Nowak S, Ozolins J, Palazon S, Potocnik H, Quenette PY, Reinhardt I, Rigg R, Selva N, Sergiel A, Shkvyria M, Swenson J, Trajce A, Von Arx M, Wolfl M, Wotschikowsky U, Zlatanova D (2015) Key actions for Large Carnivore populations in Europe. Institute of Applied Ecology (Rome, Italy). Report to DG Environment, European Commission, Bruxelles. Contract no. 07.0307/2013/654446/SER/B3

Brown JS (1999) Vigilance, patch use, and habitat selection: foraging under predation risk. Evol Ecol Res 49-71

Burkholder DA, Heithaus MR, Fourqurean JW, Wirsing A, Dill LM (2013) Patterns of top-down control in a sea grass ecosystem: could a roving apex predator induce a behavior-mediated trophic cascade? J Anim Ecol 82:1192-1202. doi:10.1111/1365-2656.12097

Camarra JJ, Parde JM (1990) The brown bear in France, status and management in 1985. Aquilo Ser Zool Tome 27:93-96

Casanova E (2005) L'ós del Pirineu. Crònica d'un extermini. Col·lecció Guímet. Pagès Editors, Lleida

Chapron G, Kaczensky P, Linnell JD, Von Arx M, Huber D, Andrén H et al (2014) Recovery of large carnivores in Europe's modern human-dominated landscapes. Science 346:1517-1519

Croll DA, Maron JL, Estes JA, Danner EM, Byrd GV (2005) Introduced predators transform subarctic islands from grassland to tundra. Science 307:1959-1961

DARP (2015) Status of the brown bear in Catalonia: 2014 (In Catalan). Non published Report

Edwards M (2014) A review of management problems arising from reintroductions of large carnivores. J Young Investig 27:11-16

Estes JA (1996) Carnivores and ecosystem management. Wildlife Soc Bul 24:390-396

Estes JA, Duggins DO (1995) Sea otters and kelp forests in Alaska: generality and variation in a community ecological paradigm. Ecol Monogr 65:75-100

Estes JA, Tinker MT, Williams TM, Doak DF (1998) Killer whale predation on sea otters linking oceanic and near shore ecosystems. Science 282:473-476

Estes JA, Crooks K, Holt R (2001) Predators, the ecological role of. In: Levin S (ed) Encyclopedia of Biodiversity, vol 4. Academic Press, San Diego, CA, pp 857-878

Estes JA, Riedman ML, Staedler MM, Tinker MY, Lyon BE (2003) Individual variation in prey selection by sea otters: Patterns, causes and implications. J Anim Ecol 72:144-155

Estes JA, Terborgh J, Brashares JS, Power ME, Berger J, Bond WJ, Carpenter SR, Essington TE, Holt RD, Jackson JBC et al (2011) Trophic downgrading of planet earth. Science 333:301-306

FitzGibbon CD, Lazarus J (1995) Antipredator behavior of Serengeti ungulates: Individual differences and population consequences. In: Sinclair ARE, Arcese P (eds) Serengeti II: dynamics, management, and conservation of an ecosystem. University of ChicagoPress, Chicago IL, pp 274-296

Frank DA (2008) Evidence for top predator control of a grazing ecosystem. Oikos 117:1718-1724

Hayward MW, Marlow N (2014) Will dingoes really conserve wildlife and can our methods tell? J Appl Ecol 51:835-838

Heithaus M, Wirsing AJ, Dill LM (2012) The ecological importance of intact top predator populations: a synthesis of 15 years of research in a sea grass ecosystem. Marine Freshw Res 63:1039-1050

Helfield J, Naiman RJ (2006) Keystone interactions: Salmon and bear in riparian forests of Alaska. Ecosystems 9:167-180

Holtgrieve G, Schindler DE (2011) Marine derived nutrients, bioturbation, and ecosystem metabolism: reconsidering the role of salmon in streams. Ecology 92:373-385

Jedrzejewska B, Jedrzejewski W (2005) Large carnivores and ungulates in European temperate forest ecosystems: bottom-up and top-down control. In: Ray JC, Redford KH, Steneck RS, Berger J (eds) Large carnivores and the conservation of biodiversity. Island Press, Washington, DC, pp 230-246 
Jedrzejewski W, Schmidt K, Milkowski L, Jedrzejewska B, Okarma H (1993) Foraging by lynx and its role in ungulate mortality: the local (Białowieża Forest) and the Palaearctic viewpoints. Acta Theriol 38:385-403

Letnic M, Ritchie EG, Dickman CR (2012) Top predators as biodiversity regulators: the dingo Canis lupus dingo as a case study. Biol Rev 87:390-413

López BH (1978) Of Wolves And Men. Charles Scribner's and Sons, New York, New York, USA

Magrama (2015a) Estudio de viabilidad de la reintroducción de lince europeo Lynx lynx en los Pirineos Centrales. Unpublished document

Magrama (2015b) Buenas prácticas para la observación de oso, lobo y lince en España. Ministerio de Agricultura, Alimentación y Medio Ambiente. Secretaría General Técnica. Centro de Publicaciones. Madrid

Maron J, Estes JA, Croll DA, Danner EM, Elmendorf SC, Buckelew SL (2006) An introduced predator alters Aleutian island plant communities by thwarting nutrient subsidies. Ecol Monogr 76:3-24

Martin J, Revilla E, Quenette PY, Naves J, Allaine D, Swenson E (2012) Brown bear habitat suitability in the Pyrenees: transferability across sites and linking scales to make the most of scarce data. J Appl Ecol 49:621-631

Matich P, Heithaus MR, Layman CA (2011) Contrasting patterns of individual specialization and trophic coupling in two marine apex predators. J Anim Ecol 80:294-305

McLaren BE, Peterson RO (1994) Wolves, moose, and tree rings on Isle Royale. Science 266:5190

Mech LD (1996) A new era for carnivore conservation. Wildlife Soc Bull 24:397-401

Melis C et al (2009) Predation has a greater impact in less productive environments: variation in roe deer, Capreolus capreolus, population density across Europe. Glob Ecol Biogeogr 18:724-734

Miller B, Dugelby B, Fopreman D, Martínez del Río C, Noss R, Phillips M, Reading R, Soulé ME, Terborgh J, Willcox L (2001) The importance of large carnivores to healthy ecosystems. Endanger Spec Updat 18:202-210

Naves et al (2015) Brown bear attacks on humans in Europe: an overview for the period 2000-2015

Nevin OT, Gilbert BK (2005) Perceived risk, displacement and refuging in brown bears: positive impacts of ecotourism? Biol Conser 121:611-622

Noss RF, Quigley HB, Hornocker MG, Merrill T, Paquet PC (1996) Conservation biology and carnivore conservation in the rocky mountains. Conser Biol 10:949-963

Okarma H (1995) The trophic ecology of wolves and their predatory role in ungulate communites of forest ecosystems in Europe. Acta Theriol 40:335-386

Ordiz A (2014) Altera el turismo de naturaleza el comportamiento de los grandes carnívoros? Quercus 341:14-21

Paine R (1966) Food web complexity and species diversity. Am Nat 100:65-75

Paine RT (1980) Food webs: linkage, interaction strength and community infrastructure. J Anim Ecol 49:666-685

Palomares F, Caro TM (1999) Interspecific killing amongmammalian carnivores. Am Nat 153:492-508

Parellada X, Alonso M, Toldrà L (1995) Ós bru. In: Ruiz-Olmo J, Aguilar A (eds) Atlas dels Grans Mamífers de Catalunya. Lynx Ed, pp 124-129

Pastor J, Naiman RJ, Dewey B (1988) Moose, microbes and boreal forests. Bioscience 38:770-777

Piédallu B, Quenette PY, Mounet C, Lescureux N, Borelli-Massines M, Dubarry E, Camarra JJ, Gimenez O (2016) Spatial variation in public attitudes towards brown bears in the French Pyrenees. Biol Conser 197:90-97

Post E, Peterson RO, Stenseth NC, McLaren BE (1999) Ecosystem consequences of wolf behavioural response to climate. Nature 401:905-907

Post DM, Pace ML, Hairston NG (2000) Ecosystem size determines food-chain length in lakes. Nature 405:1047-1049 
Power ME, Tilman D, Estes JA, Menge BA, Bond WJ, Mills LS, Daily G, Castilla JC, Lubchenco J, Paine RT (1996) Challenges in the quest for keystones. Bioscience 46:609-620

Quenette PY, Alonso M, Chayron L, Cluzel P, Dubarry E, Dubreuil D, Palazón S, Pomarol M (2000) Preliminary results of the first transplantation of brown bears in the French Pyrenees. Ursus 12:115-120

Ripple WJ, Beschta RL (2006) Linking wolves to willows via risk-sensitive foraging by ungulates in the northern Yellowstone ecosystem. For Ecol Manage 230(1-3):96-106. doi:10.1016/j. foreco.2006.04.023

Ripple WJ, Beschta RL (2012) Trophic cascades in Yellowstone: the first 15 years after wolf reintroduction. Biol Conser 145:205-213

Ritchie EG, Johnson CN (2009) Predator interactions, mesopredator release and biodiversity conservation. Ecol Lett 12:982-998

Ritchie EG, Elmhagen B, Glen AS, Letnic M, Ludwig G, McDonald RA (2012) Ecosystem restoration with teeth: what role for predators? Trends Ecol Evol 27:265-271

Rockwell D (1991) Giving voice to the bear, North American Indian myths, rituals and images of the bear. Roberts Rinehart Publishers, Niwot, Colorado, USA

Rodríguez-Varela R, Ureña I, García N, Cregut-Bonmoure E, Mannino MA, Arsuaga JL, Valdiosera C (2015) Ancient DNA evidence of Iberian lynx palaeoendemism. Quat Sci Rev 112:172-180

Rosenblatt AE, Heithaus MR, Mather ME, Matich P, Nifong JC, Ripple WJ, Silliman BR (2013) The roles of large top predators in coastal ecosystems: new insights from long term ecological research. Oceanography 26:156-167

Ruiz-Olmo J (1995) Llop. In: Ruiz-Olmo J, Aguilar A (eds) Atlas dels Grans Mamífers de Catalunya. Lynx Ed, pp 136-139

Ruiz-Olmo J (2001) El misterioso lince de los Pirineos: muchos indicios pero sin evidencias en los últimos cincuenta años. Quercus 182:12-19

Ruiz-Olmo J, Pomarol M, Macias M, Palazón S, Batet T, Lampreave G, López-Martín JM, Such-Sanz À, Camps D, Mañas F, Parellada X, RodríguezI, Alàs J (2006) Informe tècnic per a la valoració de la reintroducció del linx europeo Lynx lynx a Catalunya. Generalitat de Catalunya-Forestal Catalana

Ruiz-Olmo J, Palazón S, Camps D, Quenette PY, Batet A, Antona X, Pla M, Villero D, Decaluwe F, Brotons L, Melero Y (in press) Do reintroduced bears (Ursus arctos) present the same habitat patterns as extinct native bears in the Pyrenees? Modeling distribution and habitat quality

Sainz de la Maza P, Nunes J (2001) Los sistemas de información geográfica aplicados al estudio, la gestión y la conservación del hábitat del oso pardo (Ursus arctos) en un área del Pirineo catalán. Treballs de la Societat Catalana de Geografia 52:245-264

Schmitz OJ (1998) Direct and indirect effects of predation and predation risk in old-field interaction webs. Am Nat 151:327-340

Schmitz OJ, Hamback PA, Beckerman AP (2000) Trophic cascades in terrestrial systems: a review of the effects of carnivore removal on plants. Am Nat 155:141-153

Sergio F, Caro T, Brown D, Clucas B, Hunter J, Ketchum J, McHugh K, Hiraldo F (2008) Top predators as conservation tools: ecological rationale, assumptions and efficacy. Annu Rev Ecol Evol Syst 39:1-19

Soulé ME, Bolger ET, Alberts AC, Wright J, Sorice M, Hill S (1988) Reconstructed dynamics of rapid extinctions of chaparral-requiring birds in urban habitat islands. Conserv Biol 2:75-92

Sunde P, Overskaug K, Kvam T (1999) Intraguild predation of lynxes on foxes: evidence of interference competition? Ecography 22:521-523

Swenson JE, Dahle B, Busk H, Opseth O, Johansen T, Söderberg A, Wallin K, Cederlund G (2007) Predation on moose calves by European Brown bears. J Wild Manag 71:1993-1997

Terborgh J (1988) The big things that run the world-a sequel to E. O. Wilson. Conser Biol 2:402-403

Terborgh J, Lopez L, Tello J, Yu D, Bruni AR (1997) Transitory states in relaxing land bridge islands. In: Laurance WF, Bierregaard RO Jr (eds) Tropical forest remnants: ecology, 
management, and conservation of fragmented communities. University of Chicago Press, Chicago IL, pp 256-274

Terborgh J, Estes JA, Paquet P, Ralls K, Boyd D, Miller B, Noss R (1999) Role of top carnivores in regulating terrestrial ecosystems. In: Soulé M, Terborgh J (eds) Continental conservation: scientific foundations of regional reserve networks. Island Press, Covelo, CA, pp 39-64

Valdmann H, Andersone-Lilley Z, Koppa O, Ozolins J, Bagrade G (2005) Winter diets of wolf Canis lupus and lynx Lynx lynx in Estonia and Latvia. Acta Theriol 50:521-527

Vulla E, Hobson KA, Korsten M, Leht M, Martin AJ, Lind A, Männil P, Valdmann H, Saarma U (2009) Carnivory is positively correlated with latitude among omnivorous mammals: evidence from brown bears, badgers and pine martens. Ann Zool Fen 46:395-415

Wardle DA, Bellingham PJ, Fukami T, Mulder CPH (2007) Promotion of ecosystem carbon sequestration by invasive predators. Biol Lett 3:479-482

Weber W, Rabinowitz A (1996) A global perspective on large carnivore conservation. Conser Biol 10:1046-1055

Woodroffe R (2000) Predators and people: using human densities to interpret declines of large carnivores. Animal Conser 3:165-173

Zager P, Beecham J (2006) The role of American black bears and brown bears as predators on ungulates in North America. Ursus 17:95-108

Open Access This chapter is licensed under the terms of the Creative Commons Attribution 4.0 International License (http://creativecommons.org/licenses/by/4.0/), which permits use, sharing, adaptation, distribution and reproduction in any medium or format, as long as you give appropriate credit to the original author(s) and the source, provide a link to the Creative Commons license and indicate if changes were made.

The images or other third party material in this chapter are included in the chapter's Creative Commons license, unless indicated otherwise in a credit line to the material. If material is not included in the chapter's Creative Commons license and your intended use is not permitted by statutory regulation or exceeds the permitted use, you will need to obtain permission directly from the copyright holder.

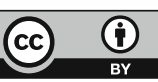

